\title{
EFEKTIVITAS FUNGI MIKORIZA ARBUSKULA DAN PUPUK P TERHADAP PERTUMBUHAN BIBIT LEDA (Eucalyptus deglupta Blume) DI MEDIA TANAH PASCA TAMBANG
}

\author{
Effectiveness of Arbuscular Mycorrhizal Fungi and P Fertilizer on Seedling Growth of \\ Leda (Eucalyptus deglupta Blume) at Post Mined Soil Media
}

Ida Rosita, Sri Wilarso B., dan Arum Sekar Wulandari

Departemen Silvikultur, Fakultas Kehutanan IPB

\begin{abstract}
Leda (Eucalyptus deglupta) is one of fast growing species that prospecting for revegetation in post mined area. Leda is able to grow in poorly soil nutrient. The aim of this research is to analyze the effectiveness of AMF and $P$ fertilizer on growth and $P$ uptake of leda seedling. This research was conducted in split plot in Completely Randomize Design (CRD). The application AMF as a main plot consisted of 5 levels, namely MO (control), M1(AMF from rubber plantation), M2 (AMF from primary forest), M3 (AMF from oil palm plantation), and M4 (AMF from natural rubber). The rock phosphate as subplot, consisted of three levels, such as $0 g P(P 0), 2 g P(P 1)$, and $5 g P(P 2)$. The result showed that interaction between AMF from rubber plantation and $2 \mathrm{~g}$ of rock phosphate significantly gave the best effect for height and diameter of Leda while interaction between AMF-primary forest (M2) and P1 (2 g of rock phosphate) reach the best of the total dry weight. Both AMF from primary forest and oil palm plantation that combined with $2 \mathrm{~g}$ of rock phosphate give the best effect but was not significantly different for P uptake and P uptake efficiency.
\end{abstract}

Key words: amf, growth, miychorrhiza, leda, p uptake, p efficiency

\section{PENDAHULUAN}

Mikoriza merupakan struktur akar yang terbentuk karen adanya asosiasi mutualisme antara fungi tanah dengan akar tanaman. Istilah simbiosis mutualisme ini seringkali digunakan untuk menggambarkan hubungan mutualistik yang saling ketergantungan, tanaman inang menerima nutrisi mineral sedangkan fungi mendapatkan senyawa karbon yang dihasilkan dari proses fotosintesis (Harley 1983). Menurut Brundett et al. (1996) fungi mikoriza memiliki peran penting dalam ekosistem alam maupun buatan. Peran tersebut diantaranya untuk tanaman berperan dalam suplai unsur hara tanaman melalui akar, antagonis terhadap organisme parasit, dan adaptif pada tanah yang kering. Pada ekosistem, mikoriza berperan dalam siklus dan konservasi unsur hara melalui miselia tanah; merupakan sumber makanan bagi banyak fauna tanah; memperbaiki struktur tanah; berperan dalam transport karbon dari akar tanaman pada organisme tanah lainnya; dan sebagai bio-indikator kualitas lingkungan dalam hal keragaman fungi. Menurut Abbott et al. (1992) efektivitas FMA tidak hanya didefinisikan sebagai kemampuan FMA untuk meningkatkan pertumbuhan tanaman pada tanah yang mengalami defisiensi fosfat, melainkan lebih bervariasi, tergantung pada pengaruh lingkungan tanah terhadap karakteristik fungi yang berhubungan dengan pembentukan dan fungsi hifa dalam tanah serta akar.

FMA merupakan mikroorganisme yang mampu bertahan dalam kondisi tanah yang kritis dan mengalami defisiensi hara seperti di lahan pasca tambang. Chen et al. (2005) menyatakan bahwa FMA yang terdapat di persemaian maupun di lapangan dapat meningkatkan pertumbuhan dan viabilitas tanaman dalam tanah yang bersifat asam dan dapat meningkatkan toleransi tanaman terhadap logam berat. Khan (2006) menegaskan bahwa pada lahan pasca tambang, nitrogen, fosfat, dan potasium mengalami defisiensi dan penyerapan oleh tanaman dapat ditingkatkan dengan adanya peran FMA. Selain itu, mikoriza dapat mengurangi stress pada kondisi lahan pasca tambang dengan suhu lingkungan yang tinggi, asam, dan kering (Salt et al. 1998).

Kegiatan penambangan umumnya menurunkan kualitas sifat fisik dan kimia tanah. Hilangnya lapisan tanah atas (top soil) terutama pada proses penambangan terbuka menjadikan tanah mengalami defisiensi hara. Selain itu, kegiatan penambangan umumnya dapat menyebabkan terpaparnya logam-logam berat ke dalam tanah sehingga menjadi toksik bagi tanaman. Kondisi ini menimbulkan pentingnya perbaikan tanah dengan penambahan pupuk disertai dengan bantuan mikroorganisme seperti FMA. Pupuk dan FMA diharapkan dapat memperbaiki kualitas tanah dan meningkatkan pertumbuhan tanaman. Upaya ini diharapkan dapat meningkatkan tingkat keberhasilan dalam proses reklamasi dan revegetasi lahan pasca tambang. Bissonnette et al. (2009) menyatakan bahwa inokulasi FMA jenis Glomus sp. dapat meningkatkan pertumbuhan tanaman Salix viminalis dalam kondisi tanah kritis dan banyak mengandung logam berat. 
Pemilihan jenis yang tepat merupakan salah satu upaya yang dapat dilakukan untuk meningkatkan keberhasilan penanaman di lahan-lahan yang kritis seperti lahan pasca tambang. Leda (Eucalyptus deglupta Blume) merupakan salah satu tanaman kehutanan yang hidup secara alami di Indonesia, Filipina, dan Papua New Guinea (Orwa et al. 2009). Leda memerlukan cahaya yang penuh dalam pertumbuhannya sehingga sangat cocok untuk ditanam di area terbuka seperti area pasca tambang. Selain itu jenis ini memiliki riap pertumbuhan yang cepat (fast growing species). Penyebaran leda cukup luas yakni dapat hidup pada area dengan ketinggian 0-1800 mdpl dan tumbuh dengan baik pada tanah yang berpasir. Leda memiliki banyak kegunaan,di antaranya dapat digunakan sebagai bahan bakar. Menurut Orwa et al. (2009) nilai energi dari kayu leda mencapai 18.500 - $21.100 \mathrm{~kJ} / \mathrm{kg}$. Dalam kegiatan reklamasi, leda mampu tumbuh di area yang tererosi dan miskin hara dan karena kulit batangnya yang cantik dengan pertumbuhan yang cepat jenis ini banyak ditanam sebagai pohon hias.

Tujuan dari penelitian ini adalah menganalisis efektivitas FMA dan pupuk $\mathrm{P}$ terhadap pertumbuhan tinggi, diameter, berat kering total, dan serapan hara $\mathrm{P}$ bibit leda di tanah pasca tambang.

\section{METODE PENELITIAN}

\section{Waktu dan Tempat Penelitian}

Penelitian dilakukan dari bulan Agustus 2015 sampai dengan bulan Februari 2016 di Laboratorium Teknologi Mikoriza dan Kualitas Bibit, Departemen Silvikultur IPB dan rumah kaca Departemen Silvikultur, Fakultas Kehutanan IPB.

\section{Prosedur Penelitian}

\section{Persiapan Inokulan}

Inokulum FMA dari empat tipe ekosistem yang berbeda diperangkap (trapping) dengan menggunakan tanaman Pueraria javanica. FMA yang telah diperbanyak diisolasi dan diidentifikasi secara morfologi. Spora yang digunakan sebagai inokulan merupakan marga yang memiliki kelimpahan terbanyak dari masing-masing tipe ekosistem.

\section{Persiapan Media Sapih dan Bibit Leda}

Media sapih yang digunakan adalah tanah pasca tambang yang berasal dari Holcim Educational Forest. Media terlebih dahulu diayak dan disterilisasi melalui proses penyangraian selama 2 jam kemudian dimasukkan ke dalam polibag berukuran $20 \mathrm{~cm} \mathrm{x} 20$ $\mathrm{cm}$. Tanah dianalisis sifat fisik dan kimianya di Balai Penelitian Tanah, Badan Penelitian dan Pengembangan Pertanian, Kementerian Pertanian. Kriteria bibit yang disapih ke dalam polibag adalah bibit yang sehat, tidak terserang hama maupun penyakit, tinggi bibit yang digunakan adalah $\pm 4 \mathrm{~cm}$, diameter $\pm 0.4 \mathrm{~cm}$ dan jumlah daun sebanyak 6 helai.

\section{Isolasi dan Kolonisasi FMA}

Teknik isolasi yang digunakan adalah teknik tuang saring dari Pacioni (1992) dalam Agustin (2011). FMA diidentifikasi secara morfologi. Identifikasi morfologi dilakukan dengan mengukur dan mengamati ukuran dan warna spora, reaksi dengan larutan melzer (lipid droplet), ornamen spora, dan bentuk hifa yang melekat pada dinding spora. Proses pewarnaan akar dilakukan dengan metode Clapp et al. (1996) untuk mengamati kolonisasi akar.

\section{Inokulasi dan Pemeliharaan}

Semai disapih dan dipelihara selama dua minggu atau sampai semai terlihat telah dapat beradaptasi (stabil) kemudian dilakukan inokulasi FMA. Inokulasi dilakukan dengan cara memberikan 30 spora FMA ke lubang tanam. Seluruh semai diletakkan di dalam rumah kaca selama tiga bulan. Penyiraman semai dilakukan dua kali sehari yaitu pada pagi dan sore hari agar media tetap lembab. Selain itu juga dilakukan pembersihan dari gulma dan perbaikan posisi polibag.

\section{Rancangan Percobaan dan Analisis Data}

Rancangan percobaan yang digunakan adalah rancangan petak terbagi (split plot design) dalam pola RAL yang terdiri dari dua faktor, yaitu faktor pemberian mikoriza (petak utama) terdiri dari lima taraf yaitu M0 (kontrol), M1 (FMA berasal dari perkebunan karet), M2 (FMA berasal dari hutan primer), M3 (FMA berasal dari perkebunan sawit), dan M4 (FMA berasal dari karet alam). Faktor pemberian pupuk rock phosphate (RP) sebagai anak petak terdiri dari tiga taraf, yaitu P0 (kontrol), rock phosphate $2 \mathrm{~g}(\mathrm{P} 1)$, rock phosphate $5 \mathrm{~g}$ (P2). Masing-masing perlakuan diulang sebanyak 8 kali.

\section{Pengamatan dan Pengumpulan Data}

Peubah yang diamati yaitu: (1) tinggi bibit, (2) diameter batang, (3) kolonisasi akar FMA, (4) berat kering total (BKT), (5) serapan hara P, dan (6) efisiensi penyerapan hara. Data tinggi dan diameter dihitung setiap dua minggu selama 3 bulan.

\section{Serapan Hara dan Efisiensi Penyerapan Hara P.}

Pengukuran kandungan unsur $\mathrm{P}$ dan $\mathrm{N}$ pada bibit yang telah diinokulasi dilakukan di Laboratorium Ilmu Tanah, Fakultas Pertanian, Institut Pertanian Bogor. Perhitungan nilai serapan hara dan efisiensi hara dilakukan dengan menggunakan rumus (Ardakani 2011).

\section{Efisiensi Penyerapan Hara}

$$
=\frac{\text { Serapan Hara Tanaman }}{\text { Jumlah hara yang ditambahkan }}
$$

Serapan Hara Tanaman

$$
=\text { Bobot Total Biomassa }
$$$$
\mathrm{x} \% \text { hara tanaman }
$$

Jumlah Hara $=$ Kandungan Hara Tanah 


\section{Analisis Data}

Data hasil pengukuran dianalisis dengan menggunakan analisis ragam program SAS 9.1. Apabila hasil analisis menunjukkan pengaruh yang nyata, maka dilakukan uji lanjut jarak berganda Duncan (Duncan's multiple range test/DMRT) dengan tingkat kepercayaan $1 \%$ dan $5 \%$.

\section{HASIL DAN PEMBAHASAN}

\section{Dimensi Pertumbuhan Leda}

Pengaruh tunggal mikoriza berpengaruh sangat nyata pada pertambahan tinggi di minggu ke-2, 4, 6, dan 10 serta berpengaruh nyata pada minggu 10 (Tabel 1). Berdasarkan data tersebut dapat dikatakan bahwa bibit leda cenderung memberikan respon yang cepat dari awal pengamatan. Hal tersebut sama halnya dengan respon bibit leda terhadap pemberian pupuk P. Faktor tunggal pupuk berpengaruh sangat nyata pada minggu ke 2, 6, dan 10 serta berpengaruh nyata pada minggu 4 dan 12. Kedua faktor tersebut berinteraksi dan memberikan pengaruh yang sangat nyata terhadap pertambahan tinggi leda minggu ke 2, 4, dan 10.

Faktor tunggal mikoriza berpengaruh sangat nyata pada minggu ke 2 dan 8 dan berpengaruh nyata pada minggu ke 4, 6, dan 12 terhadap pertambahan diameter leda. Pertambahan diameter leda cenderung lebih konstan daripada pertambahan tinggi. Faktor tunggal pupuk mempertegas bahwa pupuk berpengaruh nyata terhadap pertambahan diameter pada setiap minggu pengamatan, akan tetapi, pertambahan diameter leda untuk interaksi dari kedua faktor, cenderung lambat dikarenakan pengaruh interaksi kedua faktor tersebut hanya terlihat nyata pada minggu ke- 12 .

Pertumbuhan merupakan proses yang dilakukan oleh tanaman hidup pada lingkungan tertentu untuk menghasilkan kemajuan perkembangan dengan menggunakan faktor lingkungan seperti $\mathrm{CO}_{2}$, unsurunsur hara, air, dan radiasi matahari (Purwanti 2012). Berat kering total tanaman merupakan salah satu parameter pertumbuhan tanaman yang relatif mudah diukur. Tabel 1 menunjukkan bahwa faktor tunggal FMA tidak berpengaruh nyata terhadap berat kering total. Berat kering total dipengaruhi oleh faktor tunggal pupuk dan interaksi antara FMA dan pupuk. Hal ini mengindikasikan bahwa FMA akan bekerja optimal ketika tersedia inang yang kompatibel dan dengan adanya penambahan pupuk.

Tabel 2 menunjukkan pengaruh interaksi antara FMA dan mikoriza terhadap pertumbuhan tinggi, diameter, dan BKT leda. Interaksi yang terbaik untuk pertumbuhan tinggi adalah FMA yang berasal dari perkebunan karet dikombinasikan dengan $2 \mathrm{~g} /$ tanaman pupuk rock phosphate. Hal tersebut menunjukkan bahwa mikoriza dapat bekerja dengan baik pada dosis pupuk $2 \mathrm{~g}$. Dosis pupuk yang lebih tinggi tidak selalu memberikan hasil terbaik bagi pertumbuhan tanaman dikarenakan umumnya mikoriza memiliki respon yang berbeda-beda terhadap besarnya ketersediaan unsur $\mathrm{P}$ dan cenderung tidak berkembang secara optimal pada kondisi yang kaya hara. Menurut Ishii (2004) pembentukan simbiosis mikoriza mencapai maksimum jika kadar P dalam tanah tidak melebihi $50 \mathrm{mg} / \mathrm{kg}$ (50 ppm). Takaran $\mathrm{P}$ optimal dipengaruhi oleh bentuk $\mathrm{P}$ yang digunakan, organik maupun anorganik, mudah larut dan tidak mudah larut, serta nisbah dari $\mathrm{C}: \mathrm{N}: \mathrm{P}$ (Chen et al. 2010). Pengaplikasian FMA yang berasal dari perkebunan karet dan pupuk $2 \mathrm{~g}$ (M1P1) dapat menghemat pupuk sebanyak $3 \mathrm{~g}$. Hal tersebut terbukti dengan nilai pertambahan tinggi dari leda pada bibit yang diberi perlakuan pupuk $2 \mathrm{~g}(2.16 \mathrm{~cm})$ lebih tinggi daripada bibit yang diberi perlakuan pupuk $5 \mathrm{~g}$ tanpa FMA $(0.78 \mathrm{~cm})$ pada minggu kedua pengamatan. Selisih pertambahan tinggi pada kedua perlakuan tersebut mencapai $1.38 \mathrm{~cm}$. Pengaplikasian FMA dianggap dapat efektif meningkatkan pertumbuhan diameter leda dengan dosis pupuk yang hanya $2 \mathrm{~g}$ dengan aplikasi FMA tersebut.

Interaksi terbaik untuk BKT leda adalah interaksi antara FMA yang berasal dari hutan primer dikombinasikan dengan pupuk $2 \mathrm{~g}$. Interaksi kedua faktor tersebut terbukti secara nyata dapat meningkatkan berat kering total leda. Hal tersebut sejalan dengan penelitian Nandakwang et al. (2008) yang menyatakan bahwa interaksi antara FMA dan pupuk $\mathrm{P}$ pada tanah yang mengalami defisiensi hara terbukti dapat meningkatkan berat kering total pada tanaman Castanopsis acuminatissima. Tanaman yang memiliki berat kering lebih besar berarti produktivitas dan perkembangan sel-sel jaringannya tinggi dan cepat. Kecenderungan meningkatnya berat kering tanaman berkaitan dengan metabolisme tanaman atau karena adanya kondisi pertumbuhan yang lebih baik untuk berlangsungnya aktivitas metabolisme tanaman (Martin et al. 2004).

Tabel 1 Rekapitulasi hasil analisis ragam pengaruh FMA dan pupuk terhadap pertambahan tinggi dan diameter leda

\begin{tabular}{lccc}
\hline Waktu & FMA & Pupuk & FMA x pupuk \\
Pengamatan & \multicolumn{4}{c}{ Pertambahan tinggi } \\
Minggu 2 & $* *$ & $* *$ & $*$ \\
Minggu 4 & $* *$ & $*$ & $* *$ \\
Minggu 6 & $* *$ & $* *$ & tn \\
Minggu 8 & tn & tn & tn \\
Minggu 10 & $*$ & $* *$ & $* *$ \\
Minggu 12 & tn & $*$ & tn \\
Minggu 2 & Pertambahan diameter & \\
Minggu 4 & $*$ & $*$ & tn \\
Minggu 6 & $*$ & $*$ & tn \\
Minggu 8 & $* *$ & $* *$ & tn \\
Minggu 10 & tn & $* *$ & tn \\
Minggu 12 & $*$ & $* *$ & tn \\
Minggu 12 & Berat Kering Total (BKT) & $* *$ \\
tn & $* *$ & $* *$
\end{tabular}

$* *=$ berpengaruh sangat nyata; $*=$ berpengaruh nyata; tn=tidak berpengaruh nyata, FMA= fungi mikoriza arbuskula 
Tabel 2 Hasil uji lanjut Duncan pengaruh interaksi FMA dan pupuk terhadap pertambahan tinggi, diameter, dan BKT

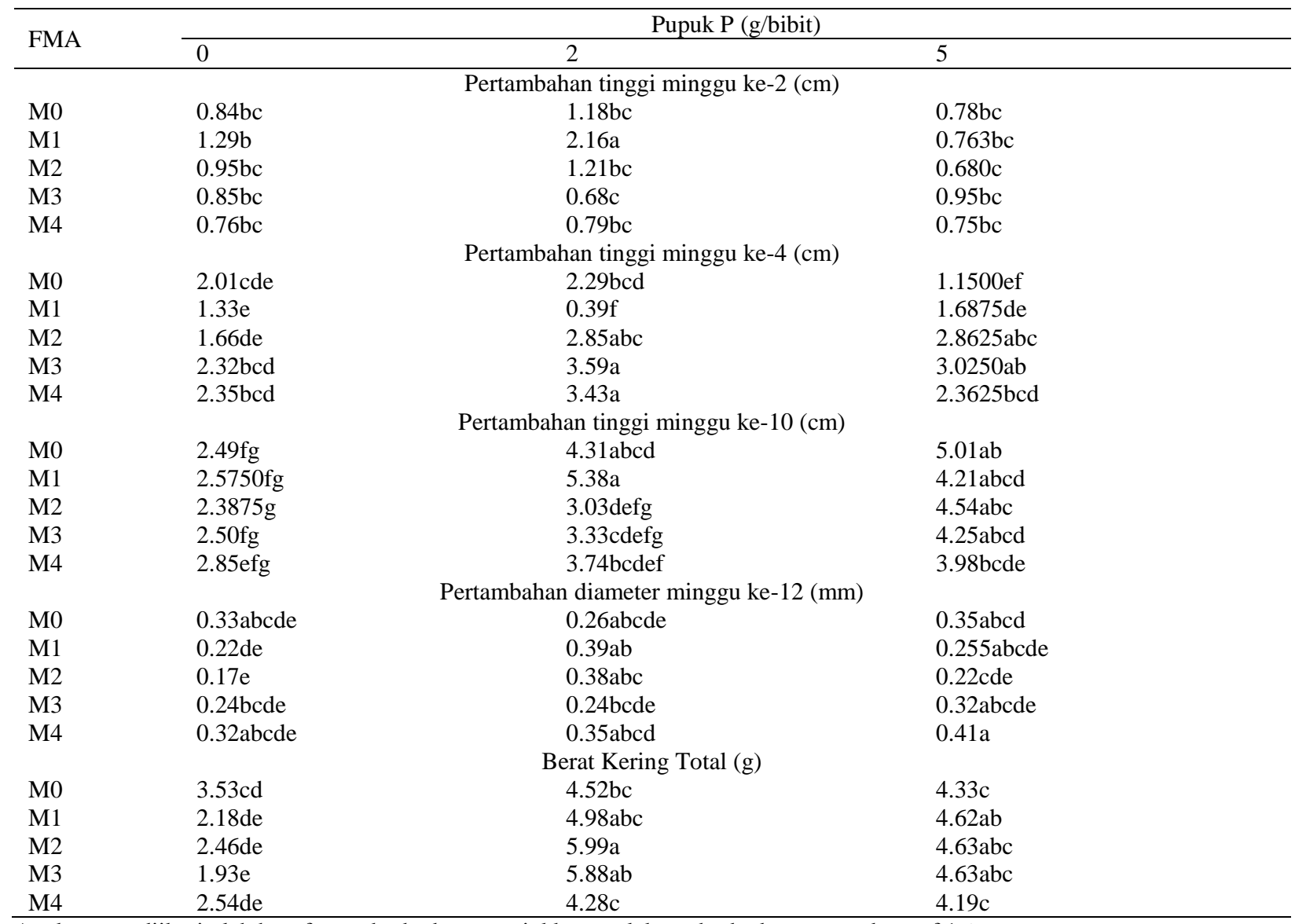

Angka yang diikuti oleh huruf yang berbeda menunjukkan perlakuan berbeda nyata pada taraf $1 \%$

M0=tanpa FMA; M1=FMA berasal dari perkebunan karet; M2=FMA berasal dari hutan primer; M3=FMA berasal dari perkebunan sawit; M4=FMA berasal dari ekosistem karet alam, FMA=fungi mikoriza arbuskula; BKT=berat kering total

\section{Kolonisasi FMA}

Gambar 1 menunjukkan nilai persentase kolonisasi pada setiap akar tanaman yang diberikan perlakuan FMA. Nilai persen kolonisasi tertinggi terdapat pada akar bibit leda yang diinokulasi FMA yang berasal dari hutan primer tanpa penambahan pupuk yaitu sebesar $83.33 \%$. Besarnya kolonisasi tersebut ternyata tidak berbanding lurus dengan pertumbuhan tanaman. Menurut Smith et al. (2008) FMA mampu mengkolonisasi jaringan akar tanaman inang melalui kombinasi mekanisme mekanik dan enzimatik juga disertai dengan adanya sinyal dari tanaman inang sendiri berupa eksudat akar.

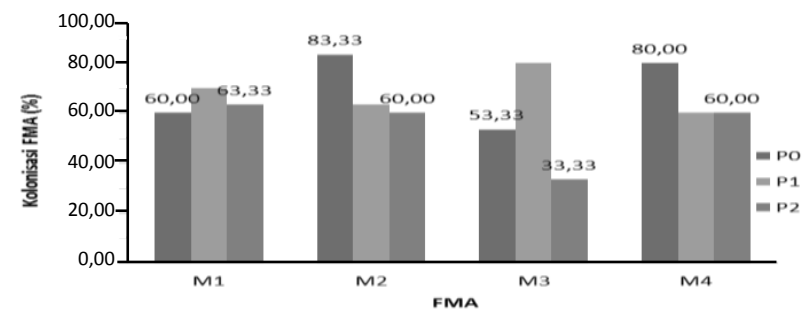

Gambar 1 Persentase akar leda yang terkolonisasi FMA

Berdasarkan Gambar 1 nilai persen kolonisasi terendah terdapat pada FMA yang berasal dari perkebunan sawit dikombinasikan dengan $5 \mathrm{~g}$ pupuk rock phosphate. Sebagian besar nilai persentase kolonisasi FMA berada pada kisaran 53.33-63.33\%. Besarnya kolonisasi akar tidak selalu berbanding lurus dengan pertumbuhan tanaman yang dikolonisasi mengingat kemampuan dari FMA dalam mengikat unsur hara dari tanah dan mentransfer kembali hara tersebut ke dalam akar tanaman berbeda-beda. Pernyataan ini dipertegas oleh Corkidi et al. (2004) yang menyatakan kolonisasi atau infektivitas yang tinggi tidak selalu berkorelasi positif dengan keuntungan yang didapatkan oleh tanaman inang. Simbiosis FMA dikatakan efektif jika mampu menghasilkan pengaruh menguntungkan tertentu terhadap tanaman inang atau lingkungan pertumbuhannya.

Menurut Cavagnaro et al. (2003) inokulan FMA dikatakan efektif untuk inang jika dapat meningkatkan bobot kering tanaman dan serapan hara, terutama unsur P. Menurut O'Conor et al. (2001) seluruh nilai kolonisasi pada semua perlakuan tergolong ke dalam kategori tinggi yakni lebih dari $30 \%$.

\section{Serapan Unsur Hara P}

Unsur P sangat penting untuk pertumbuhan tanaman dan mencapai $0.2 \%$ dari berat kering total tanaman, akan tetapi merupakan unsur hara yang sangat sulit untuk diserap tanaman. Selain unsur $\mathrm{P}$ mudah diikat oleh unsur lain seperti $\mathrm{Al}, \mathrm{Fe}$, dan $\mathrm{Ca}$, tanaman dan 
fungi mengambil unsur $\mathrm{P}$ dalam bentuk ion negatif $\left(\mathrm{H}_{2} \mathrm{PO}_{4}^{-}\right)$. Hal tersebut menyulitkan tanaman dalam menyerap fosfat karena konsentrasi dalam sel tanaman 1000 kali lebih tinggi daripada ion tersebut dan membran sel juga memiliki potensial ion negatif. Oleh karena itu, penyerapan P memerlukan energi metabolik yang tinggi dan melibatkan protein transporter yang memiliki daya serap tinggi (Bucher 2007). Selain itu peran FMA dapat membantu meningkatkan serapan hara dengan beberapa mekanisme seperti dengan membentuk hifa eksternal sehingga dapat menjangkau hara $\mathrm{P}$ lebih jauh daripada akar dan mengubah kondisi biokimia dan fisiologis rizosfer sehingga meningkatkan aksesibilitas $\mathrm{P}$ ke dalam akar. Tabel 3 menunjukkan hasil analisis ragam pengaruh FMA dan pupuk terhadap serapan dan efisiensi serapan hara P. Fakor tunggal FMA, pupuk, dan interaksi kedua faktor tersebut berpengaruh nyata terhadap serapan hara sedangkan pada efisiensi hara hanya faktor pupuk dan interaksi kedua faktor yang berpengaruh nyata.

Tabel 3 Rekapitulasi hasil analisis ragam pengaruh FMA dan pupuk terhadap serapan dan efisiensi hara $\mathrm{P}$

\begin{tabular}{|c|c|c|c|}
\hline Parameter & FMA & Pupuk & FMA x pupuk \\
\hline Serapan Hara & $*$ & $* *$ & $*$ \\
\hline Efisiensi Hara & tn & $* *$ & $*$ \\
\hline
\end{tabular}

Tabel 4 menunjukkan bahwa interaksi antara FMA yang berasal dari hutan alam dengan pupuk P $2 \mathrm{~g}$ memberikan nilai terbaik untuk serapan dan efisiensi hara P. Akan tetapi, interaksi ini tidak berbeda nyata dengan interaksi antara FMA yang berasal dari perkebunan sawit dan pupuk $2 \mathrm{~g}$.

Serapan dan efisiensi hara $\mathrm{P}$ bibit leda yang diberi perlakuan FMA (M2 dan M3) dikombinasikan dengan 2 g pupuk rock phopshate secara statistik lebih tinggi daripada bibit yang diberi perlakuan pupuk $5 \mathrm{~g}$ dan tanpa inokulasi FMA (M0P2). Hal tersebut selaras dengan pernyataan Bustami et al. (2012) apabila kadar $P$ berlebihan, maka serapan unsur lain di dalam tanah akan terganggu sehingga akan menghambat pertumbuhan tinggi tanaman. Selain itu, pemakaian unsur hara secara berlebihan, akan mengakibatkan terjadi penimbunan unsur hara tersebut di vakuola. Efisiensi penyerapan unsur hara $\mathrm{P}$ dihitung berdasarkan rumus yang dikembangkan oleh Ardakani (2011). Berdasarkan hasil analisis ragam, faktor tunggal mikoriza tidak berpengaruh nyata terhadap nilai efisiensi penyerapan hara. Akan tetapi, berpengaruh sangat nyata ketika diinteraksikan dengan pupuk. Fakta ini menunjukkan bahwa untuk meningkatkan penyerapan hara FMA tidak dapat berdiri sendiri tanpa pupuk.

Efisiensi penyerapan unsur hara $\mathrm{P}$ merupakan perbandingan antara besarnya serapan hara $\mathrm{P}$ tanaman dengan jumlah total unsur hara yang diberikan. Berdasarkan hasil analisis ragam, faktor tunggal FMA dan interaksi antara FMA dan pupuk $P$ tidak berpengaruh nyata terhadap efisiensi penyerapan hara. Berbeda halnya dengan faktor pupuk, pupuk $\mathrm{P}$ memberikan pengaruh yang nyata terhadap efisiensi penyerapan hara. Nilai efisiensi penyerapan hara akan tinggi ketika dilakukan penambahan pupuk P. Beberapa cara FMA dalam meningkatkan serapan hara di antaranya: 1) perluasan areal permukaan karena adanya hifa ekternal yang berukuran lebih kecil 1/10 dibandingkan akar, 2) mempercepat pergerakan $\mathrm{P}$ ke akar sehingga mengurangi konsentrasi ambang yang diperlukan untuk $\mathrm{P}$ berdifusi, 3) mengubah lingkungan rizosfer secara kimia misalnya melalui pelepasan asam organik dan peningkatan aktivitas fosfatase, dan 4) meningkatkan produksi fitohormon yang dapat mengubah fenotip akar yaitu dengan pembentukan akar dengan orde yang lebih tinggi serta membuat umur akar menjadi lebih lama dan akhirnya dapat meningkatkan kapasitas penyerapan hara total (Ocrutt dan Nielsen 2000).

Tabel 4 Pengaruh interaksi FMA dan pupuk terhadap serapan hara dan efisiensi hara

\begin{tabular}{llll}
\hline \multirow{2}{*}{ FMA } & \multicolumn{3}{c}{ Pupuk P (g/tanaman) } \\
\cline { 2 - 4 } & 0 & 2 & 5 \\
M0 & $0.25 \mathrm{~cd}$ & Serapan Hara (g/tanaman) & $0.30 \mathrm{bc}$ \\
M1 & $0.17 \mathrm{de}$ & $0.36 \mathrm{ab}$ & $0.42 \mathrm{a}$ \\
M2 & $0.17 \mathrm{de}$ & $0.40 \mathrm{ab}$ & $0.32 \mathrm{abc}$ \\
M3 & $0.14 \mathrm{e}$ & $0.42 \mathrm{a}$ & $0.42 \mathrm{a}$ \\
M4 & $0.15 \mathrm{de}$ & $0.41 \mathrm{a}$ & $0.29 \mathrm{bc}$ \\
& & $0.39 \mathrm{ab}$ & $0.009 \mathrm{bcd}$ \\
M0 & $0.008 \mathrm{def}$ & Efisiensi Hara & $0.012 \mathrm{abc}$ \\
M1 & $0.006 \mathrm{efg}$ & $0.012 \mathrm{abcd}$ & $0.009 \mathrm{bcd}$ \\
M2 & $0.006 \mathrm{efg}$ & $0.013 \mathrm{ab}$ & $0.012 \mathrm{abc}$ \\
M3 & $0.004 \mathrm{~g}$ & $0.014 \mathrm{a}$ & $0.008 \mathrm{def}$ \\
M4 & $0.005 \mathrm{fg}$ & $0.014 \mathrm{a}$ & $0.013 \mathrm{ab}$ \\
\hline
\end{tabular}

Angka yang diikuti oleh huruf yang berbeda menunjukkan perlakuan berbeda nyata pada taraf 5\%)

M0=tanpa FMA; M1=FMA berasal dari perkebunan karet; M2=FMA berasal dari hutan primer; M3=FMA berasal dari perkebunan sawit; M4=FMA berasal dari ekosistem karet alam, FMA=fungi mikoriza arbuskula 


\section{KESIMPULAN}

FMA dan pupuk berpengaruh nyata terhadap pertumbuhan tinggi, diameter, berat kering total, serapan dan efisiensi hara dari bibit leda. Interaksi FMA yang berasal dari perkebunan karet dengan pupuk $2 \mathrm{~g}$ memberikan pengaruh terbaik untuk pertumbuhan tinggi dan diameter leda. Berat kering total terbaik diperoleh dari hasil interaksi antara FMA yang berasal dari hutan primer dan pupuk $2 \mathrm{~g}$. Interaksi antara mikoriza yang berasal dari perkebunan sawit dan dosis pupuk $2 \mathrm{~g}$ serta mikoriza yang berasal dari hutan primer memberikan nilai serapan hara tertinggi.

\section{SARAN}

Pengujian lebih lanjut bibit leda yang telah diinokulasi oleh FMA dari empat tipe ekosistem yang berbeda perlu dilakukan di lapangan. Pengujian FMA dapat dilakukan pada jenis-jenis tanaman kehutanan lainnya terutama yang tergolong ke dalam fast growing species.

\section{DAFTAR PUSTAKA}

Abbott LK, Robson AD, Jasper DA, Grazey C. 1992. What is the role of VA mycorhizae hyphae in Soil. Didalam: Read DJ, Lewis DH, Fitter AH, Alexander IJ, editor. Mychorrhizae in Ecosystems. United Kingdom: CAB Internasional. hlm 37-41

Agustin W. 2011. Inokulasi fungi mikoriza arbuskula dalam meningkatkan produktivitas dan mutu benih Cabai (Capsicum annum L) serta efiseinsi penggunaan pupuk $\mathrm{P}$ [Disertasi]. Bogor (ID): Institut Pertanian Bogor.

Ardakani MR, Mazaheri D, Mafakheri S, Moghaddam A. 2011. Absorption efficiency of N, P, K through triple inoculation of wheat (Triticum aestivum L.) by Azosprillum brasilense, Streptomyces sp., Glomus intraradices and manure application. Physiology and Molecular Biology of Plant 17:181-192.

Bissonnete L, Arnaud M, Lebrecque M. 2009. Phytoexraction of heavy metal by two Salicaceae clones in symbiosis with arbuuscular mycorrhizal fungduring the second year of field trial. Plant Soil 332:55-67

Brundrett MC, Bougherr N, Dells B, Grove T, Malajczuk N, 1996. Working with mycorrhizas in forestry and agriculture. Canberra (AU): Australian Centre for International Agricultural Reserach.

Bustami, Sufardi, Bakhtiar. 2012. Serapan hara dan efisiensi pemupukan phosfat serta Pertumbuhan padi varietas lokal. Jurnal Manajemen Sumberdaya Lahan 1(2):159-170.

Cavagnaro TR, Smith FA, Ayling SM, Smith SE. 2003. Growth and phosporus nutrition of a parys-type arbuscular mycorrhizal symbiosis. New Phytol. 157:127-134.
Chen B, Tang X., Zhu Y, Christie P. 2005. Metal concentrations and mycorrhizal status of plants colonizing copper mine tailings: potential for revegetation. Science in China Ser. C Life Sciences 48(1): 156-164.

Chen MM, Yin HB, O' Connor P, Wang YS, Zhu YG. 2010. C:N:P Stoichimetry and spesific growth rate of clover colonized by arbuscular mycorrhizal fungi. Plant Soil 326:21-29.

Clapp JP, Fitter AH, Merryweather JM, 1996. Methods for the Examination of Organismal Diversity in the Soil and Sediments. Wallingford, UK: CAB International. Page 145-161.

Corcidi L, Alle EB, Merhain D, Allen MF, Downer J, Bohn J, Evan M. 2004.Assesing the infectivity of commercial mycorrhizal inoculation in plant nursery conditions. J Environ Hert 22(3):149154.

Hardjowigeno S. 2007. Ilmu Tanah. Jakarta: Akademika Pressindo.

Harley JL, Smith SE. 1983. Mycorrhizal Symbiosis. Academic Press.

Ishii T. 2004. Vesicular-Arbuscular (VA) Mycorrhiza [internet] (diakses 12 Maret 2016). Tersedia pada: http://www.bio.kpu.ac.jp/pomlab/VAMinf.html

Khan AG. 2006. Mycorrhizoremediation-an enhanced form of phytoremediation. Journal of Zhejiang University Science. 7(7):503-514.

Martin E, Islam S, Rahman T. 2004. Pengaruh endomikoriza dan media semai terhadap pertumbuhan pulai, bungur, mangium dan sungkai di persemaian. Jurnal Penelitian Hutan tanaman 1(3): 105-115.

Nandakwang P, Elliot S, Youpensuk S, Lumyong S. 2008. Effects of arbuscular mycorrhyzal inoculation and fertilizer on production of Castanopsis acuminatissima saplings for forest restoration in Northern Thailand. Journal of Microbiology 3(4): 225-236.

Nusantara AD. 2011. Pengembangan dan pemanfaatan inokulan fungi mikoriza arbuskula berbasis bahan alami untuk produksi bibit jati (Tectona grandis L.f). [disertasi]. Bogor (ID): Institut Pertanian Bogor.

O'Connor PJ, Smith SE, Smith FA. 2001.Arbuscullar mycorrhizal association in the Southern Simpson desert. Aust J Bot 49:493-499.

Ocrutt DM, Nilsen ET. 2000. Physiology of Plant Under Stress-Soil and Biotic Factor. New York: John Wiley.

Orwa C, Mutua A, Kindt R, Jamnadass R, Anthony S. 2009 Agroforestree Database: a tree reference and selection guide version 4.0 [internet] (diunduh 12 Pebruari 2016). Tersedia pada: (http://www.worldagroforestry.org/sites/treedbs/t reedatabases.asp).

Pacioni G. 1992. Wet-sieving and decanting techniques for the extraction of spores of vesiculararbuscular fungi. 317-322. In Norris JR, ReadDJ, Varma AK, editor. Methods in Microbiology. London (GB): Academic Press. 
Purwanti SI. 2012. Respon pertumbuhan Calliandra calothyrsus Meissn. dan Calliandra tetragona Benth. terhadap pemberian fungi mikoriza arbuskula dan arang tempurung kelapa [skripsi]. Bogor (ID): Institut Pertanian Bogor.
Salt DE, Smith RD, Raskin I. 1998. Phytoremediation. Annual Review of Plant Physiology 49:643-668. Smith SE, Read D. 2008. Mycorrhizal Symbiosis Third Edition. Academic Press: New York. 